\title{
THE INCENTIVE EFFECTS OF PROPERTY TAXES ON LOCAL GOVERNMENTS
}

\author{
Edward L. Glaeser
}

Working Paper No. 4987

\section{NATIONAL BUREAU OF ECONOMIC RESEARCH 1050 Massachusetts Avenue \\ Cambridge, MA 02138 \\ January 1995}

I am grateful to Jerry Lauretano for his helpful discussions of Somerville politics. National Science Foundation Grant SBR-9309808 and the Tozier/Clark fund of Harvard University both provided helpful funding. Judith Chevalier and James Hines provided encouraging discussions. I particularly thank an anonymous referee for helpful comments. This paper is part of NBER's research programs in Growth and Public Economics. Any opinions expressed are those of the author and not those of the National Bureau of Economic Research.

(C) 1994 by Edward L. Glaeser. All rights reserved. Short sections of text, not to exceed two paragraphs, may be quoted without explicit permission provided that full credit, including $\odot$ notice, is given to the source. 


\title{
THE INCENTIVE EFFECTS OF PROPERTY TAXES ON LOCAL GOVERNMENTS
}

\begin{abstract}
This paper applies the ideas of Brennan and Buchanan $(1977,1978,1980)$ to local property taxes. When local governments maximize their revenues, property taxes provide incentives for adequate amenity provision. Local amenity provision determines property values which then determine local tax revenues. As long as the demand for housing is inelastic, property-taxes will provide stronger incentives for local governments than lump-sum taxes. As current property values reflect expectations about future amenity levels, property taxes create incentives for even the most myopic government to invest for the future. Local property taxes can also act to limit the incentives of localities to tax; there are cases where higher levels of local property taxes lead to lower overall tax burdens. These ideas are applied to the tax reform in the late 1970s; one reason that tax reform may have been so successful is that in a period where land prices are driven by many forces other than government amenities, property taxes lose their value as incentive devices.
\end{abstract}

Edward L. Glaeser Department of Economics 113 Littauer Center Harvard University Cambridge, MA 02138 and NBER 


\section{Introduction}

The bulk of optimal taxation literature focuses on minimizing the distortions to individual behavior created by most taxes. Following Ramsey (1927), optimizing tax structure usually means minimizing the misallocation of resources while raising a fixed amount of government income, which usually means taxing goods that are inelastically supplied and demanded. Examples of these misallocations range from underconsumption of a particular commodity (due to a tax on that commodity) to overall underinvestment (due to the taxation of interest income). A second, often overlapping literature, has dealt with structuring taxes to achieve equity-related goals; Atkinson and Stiglitz (1980) review these two literatures in detail.

This paper is part of a third and much smaller literature on optimal taxation. Following Brennan and Buchanan (1978), there has been a concern with the ways in which tax structure can influence governmental behavior. This literature assumes that (1) voters have an ability to set rules (a "constitution") that restrict the government and (2) governments are revenue-maximizing "leviathans" (or leviathan want-to-be's). If there are rules concerning the type of taxes that can be levied, or the level of tax rates, then governments will maximize their revenues subject to these rules, and given that the government will maximize subject to the rules in the constitution, the voters can optimally design the constitution to create the right incentives for government.

This line of reasoning has been used both positively and normatively. Brennan and Buchanan (1980) use this reasoning normatively to support Proposition 13 and tax reform generally. ${ }^{1}$ This paper uses the positive implications of the theory. I suggest, here, that the incentive role of taxation may be particularly useful in explaining the prevalence of local property taxes for financing local government expenditures.

Property taxes are ubiquitous. In the past they have provided mammoth shares of state and local revenues $(77.7 \%)$ and one-half of total U.S. tax

\footnotetext{
${ }^{1}$ Brennan and Buchanan (1978) focus primarily on the positive implications of the theory.
} 
revenues (as of 1927, according to Maxwell (1965)). Currently (as of 1989) they still provide a large share of particularly local revenues; $74 \%$ of local government tax revenues across the United States come from property taxes. ${ }^{2}$

The dependence on property taxes has been traditionally justified in many ways (see Rosen (1986) for a basic summary). If property is inelastically supplied and demanded, then property taxes can be justified (following standard Ramsey-rule reasoning) as minimizing distortions. When property ownership is related to individuals' use of local public goods, i.e. more property more use of police, then property taxes can be justified as user fees. Finally, following Henry George (1935), property taxes can be justified on equity grounds. Maxwell's (1965) explanation is that localities just have few options; taxing other commodities will lead to out-migration quickly. ${ }^{3}$ Of course, there is some truth to all of these justifications.

This paper presents another justification for the property tax based on observation of local government actions in the Boston area. ${ }^{4}$ Property taxation can provide strong incentives for governments to provide the amenities that people value. ${ }^{5}$ I present three models of government activity when governments maximize revenues and property taxes are a major source of government revenues, as indeed they are in the case of local governments.

In the first model, 6 property taxation is shown to provide powerful incentives for governments to provide basic amenities. Since those amenities raise

\footnotetext{
${ }^{2}$ In fact, tax revenues are only $29 \%$ of total local government revenue. The bulk of local goverrnmental revenues come from intergovernmental transfers. My source for these figures is the Statistical Abstract of the United States.

${ }^{3}$ Maxwell's argument seems to be a version of the inelasticity argument. In his case, he views the local government as a revenue maximizer who taxes the inelastically supplied commodity because it maximizes revenues. The more traditional inelasticity argument is that taxing the inelastic good is Pareto-superior.

${ }^{4} \mathrm{My}$ source on these matters is Jerry Lauretano of Jerry's Underground Barber Shop, who has related to me his attempts to foster local government action on neighborhood beautification (trees on sidewalks, etc.). The most effective tool for engaging local officials is, according to him, convincing them that these trees will raise property values.

${ }^{5}$ Throughout the paper, I will use the word amenity loosely. I mean by an amenity every government action from schools to policing.

I refer to three models. In fact, these "models" are minor perturbations on the same basic model of government and voter behavior.
} 
property values, they also raise tax revenues. Contrary to the arguments of Maxwell (1965), lump-sum taxes are both feasible and do provide incentives for government, ${ }^{7}$ but as long as the demand for housing is sufficiently inelastic, property taxes provide better incentives for local governments than lump sum taxes.

It is obvious, in the model, that property taxes provide much better incentives for local governments than they would for national governments. Higher nationwide amenity levels will not act to raise national property values in our model while local amenity improvements will raise local property values (as long as other localities amenities are not improved identically). This fact may explain why property taxes are so much more prevalent on the local than on the national level. Other theories of property taxes (i.e. the inelasticity argument) do little to explain why property taxes are much more common on the local than on the national level. ${ }^{8}$

The second model of incentives and property taxation suggests another benefit of property taxes. Local government officials may be more myopic than the citizenry at large, perhaps because of the short time horizons created by electoral uncertainty. Property taxes may undo some of this myopia. Since property values will reflect, immediately, expectations about improvements in future amenity levels, taxes based on property values will induce politicians to worry about the future. This point is fairly general and would apply to taxes on any form of capital stock.

The first two models assumed a fixed property tax level and then examined local government behavior taking the property taxes as fixed. The third model allows local government to determine tax rates subject to potential voter unrest. While property taxes are not naturally self-limiting (in the sense that the revenue-maximizing tax on a highly elastically supplied good will be less than infinite), property taxes do serve to limit taxes on all other commodities. A rise in taxes on other commodities will lower property

${ }^{7}$ Lump sum taxes create incentives because they create an incentive for governments to want to attract more inhabitants.

${ }^{8}$ In fact, there are more distortions (mostly migrational) created by property taxes on the local level than there would be by property taxes on the national level. Ramsey-rule taxation would predict that property taxes would be more common at the national level. 
values and thus lower property tax revenues. The property tax gives the government an incentive to restrict taxation on other commodities. In particular, I give conditions under which an increase in the property tax rate will lower the total tax burden on the community.

The paper concludes by presenting a discussion of tax reform in the late 1970s. The incentive view of local property taxation provides a second reason why the case of Serrrano $v$. Priest (which limited local government discretion over education) might make it more appealing to limit the property tax. Moreover, I believe that the highly volatile land markets of the late 1970 s made the property taxes much poorer incentive devices than they had been earlier. The amount of information that property values carried about local government competence declined because of the overall price volatility (and next to local property taxes). Restricting property tax revenues was a natural response since these revenues had become much less effective as incentives.

\section{Model 1: Local Property Taxes and Amenity Provision}

This section presents a model of the incentive effects of property taxes. While it would be trivial to show that property taxes provide incentives, the goal is to compare property taxes with a reasonable comparison tax. The property tax is here compared with lump-sum taxes (frequently an optimal tax). In the model both forms of taxation provides incentives for amenity provision. When the government provides amenities, more people want to live in the community and the revenues from lump-sum taxes rise. When the government provides amenities, more people want to live (and therefore own land) in the community and property values, and hence revenues from property taxes, rise. The main result of this model is the condition under which a revenue neutral switch from lump-sum taxes to property taxes increases the overall level of incentives facing local governmerits.

The comparison between the incentive effects of the two forms of taxation hinges on the elasticity of demand for housing. When demand for housing is inelastic (less than one), improvements in local amenity value show up mainly in higher housing prices. When demand for housing is elastic, 
highcr amenity levels lead to more inhabitants and smaller lot sizes -- land prices change less and the incentive effects of property taxes are weaker.

I assume that there is a fixed supply of land in the community. If land supply was more flexible (perhaps because of the ability to build taller buildings), the elasticity of housing supply would also determine the optimality of land taxes. Greater amounts of inelasticity (in this case, of supply) would make land taxes stronger as incentive devices.

I assume that there are an arbitrarily large number (denoted $Q$ ) of locations of area one. Each one of these locations is an independent political jurisdiction with the ability to set its own amenity levels but not its tax levels. The total population is set at $Q$ as well. All locations are identical and I will look at symmetric equilibria, so in equilibrium, the population of each location will be one. ${ }^{9}$

There are three layers of optimization in this model. Consumers will choose location and land quantities taking as given the tax rates and the provision of local amenities. Governments will choose the level of local amenities that maximize their revenues taking as given (1) other local governments' decisions about amenity levels, (2) the overall tax rates, and (3) consumers' reaction functions. Each government takes the other local governments decisions as given because I am interested in the Nash equilibria of this game and because modeling the full range of strategic interactions that can exist across space is beyond the scope of this paper. Voters (or equivalently a benevolent social planner) will choose the tax rates before either of these choices are made (i.e. they will write a constitution). Voters will assume that the governments' and consumers' actions are flexible but that these agents (the governments and consumers) will behave optimally given the tax rate.

The assumption about tax rates being fixed will be relaxed in Model 3. I can justify this assumption as either a version of Proposition 2.5 in Massachusetts (where local property rates are set by law), or of any one of the 19 restrictions

\footnotetext{
9 This assumption means that we do not need to worry about distortions in land consumption coming from the form of taxation since no matter what tax rates apply the land density will always be one.
} 
on local determination of tax rates in the United States (see Preston and Ichniowski (1991) for a review). The assumption could also be justified by claiming that tax rates are easy to monitor by voters who punish governments that overtax, while amenity levels are harder to monitor (so the government knows that its tax rates are fixed but its amenity levels are flexible). A third justification of the is that if there are divisions within the government, and one group (the legislative branch) determines the tax rate while another group (the executive branch) determines the amenity level.

The solution to this model requires working backwards, solving the consumer's problem first. The consumer's problem is to maximize:

(1) $U\left(X, L, A_{j}\right)$ subject to $I \geq X+P_{j}\left(1+t_{j}\right) L+B_{j}$.

$\mathrm{U}(., \ldots)$ is a utility function common across consumers. I represents income. $\mathrm{X}$ is a composite commodity with a price of one. L reflects the consumption of land; $P_{j}$ is the price of land in location $j . A_{j}$ reflects the amenity levels in location $j . \quad B_{j}$ is the lump-sum tax (or equivalently income tax) ${ }^{10}$ in location $j$ and $t_{j}$ is the property tax in location $j$. Since the equilibrium is symmetric across locations, I will drop the $\mathrm{j}$ subscripts for notational simplicity.

Also in the spirit of simplicity I will look at case of a separable utility function where the utility from the composite commodity is linear, or formally:

(1') $U(X, L, A)=X+f(L)+g(A)=I-B-P(1+t) L+f(L)+g(A)$,

where $f($.$) and g($.$) are concave functions. The first order condition for land$ consumption is:

(2) $P(1+t)=f^{\prime}(L), 11$

10 This equivalence holds because labor supply is inelastic in this model.

${ }^{11} \mathrm{I}$ assume sufficient concavity throughout these models so that second order conditions will always hold. 
which defines (through the implicit function tileorem) a quantity, $L(P)$, which reflects the optimal land consumption in this community given prices and taxes. Differentiating (2) reveals that:

(3) $L^{\prime}(P)=(1+t) / f^{\prime \prime}(L)$.

It is convenient to define here the elasticity of housing demand as

$\left(3^{\prime}\right) \varepsilon_{D}=-(P(1+t) / L) L^{\prime}(P)=-P(1+t) / f^{\prime \prime}(L) L$,

(or $-\mathrm{P}(1+t)^{2} / \mathrm{f}^{\prime \prime}(\mathrm{L})$ when $\mathrm{L}=1$ as it does in equilibrium).

Individuals must also be indifferent across locations, so that within each location:

(4) $\mathrm{I}-\mathrm{B}-\mathrm{P}(1+\mathrm{t}) \mathrm{L}(\mathrm{P})+\mathrm{f}(\mathrm{L}(\mathrm{P}))+\mathrm{g}(\mathrm{A})=$ Reservation Utility.

Equations (2) and (4) represent the solutions to the consumer's problem when $A, t$, and $B$ as given. It is also helpful here to define the quantity $P^{\prime}(A)$ : the extent to which changes in amenity levels change the price of land.

(5) $-P^{\prime}(A)(1+t) L(P)-P(A) P^{\prime}(A)(1+t) L^{\prime}(P)+f^{\prime}(L) L^{\prime}(P) P^{\prime}(A)+g^{\prime}(A)=0$,

or substituting using (2):

(6') $P^{\prime}(\mathrm{A})=g^{\prime}(\mathrm{A}) /(1+\mathrm{t}) \mathrm{L}$.

This equation gives the positive relationship between the level of amenities provided by the government and the overall cost of land. Likewise, it is useful to remember that

(7) $\mathrm{N}(\mathrm{A}) \mathrm{L}(\mathrm{P}(\mathrm{A}))=1$.

Differentiating (7) tells us that:

(8) $N^{\prime}(A) L(P(A))=-N(A) L^{\prime}(P) P^{\prime}(A)$, or substituting, that: 
(8) $N^{\prime}(A)=-g^{\prime}(A) N / f^{\prime \prime}(L) L^{2}$.

This equation shows the positive relationship between the level of amenities and population of the area -- the relationship is always positive. However, while it is almost impossible to conceive of a situation where government amenity levels reduce property values, it is easy to write a model in which $\mathrm{N}^{\prime}(\mathrm{A})$ is negative. If rising amenity levels attract richer residents who demand higher plots of land then an increase in amenity values may not raise population at all. In that case, lump-sum taxes would perversely provide an incentive for the government to reduce amenity levels; only property taxes provide the right incentive.

The maximization problem for the local government takes $P(A), N(A), t$ and $B$ as parameters of the systems. The local government can only maximize setting the level of $\mathrm{A}$. The governments total revenues are:

(9) $P(A) t+N(A) B-A$,

since the government has exactly one unit of land and I normalize the cost of amenity levels to be one.12 (9) yields first order condition:

(10) $P^{\prime}(A) t+N^{\prime}(A) B-1=0$,

or using $\left(6^{\prime}\right)$ and $\left(8^{\prime}\right)$ :

$\left(10^{\prime}\right) \operatorname{tg}^{\prime}(\mathrm{A}) /(1+\mathrm{t}) \mathrm{L}-\mathrm{Bg}^{\prime}(\mathrm{A}) \mathrm{N} / \mathrm{f}^{\prime \prime}(\mathrm{L}) \mathrm{L} 2-1=0$, or

(11) $A=g^{\prime-1}\left[\left(f^{\prime \prime}(L)(1+t) L^{2} /\left(t f^{\prime \prime}(L) L-B N(1+t)\right)\right]\right.$

This function describes the overall level of amenities that the local government will provide given a particular tax code. The tax code is written, knowing that $\mathrm{L}$ and $\mathrm{N}$ will equal one in equilibrium (no matter what the tax

\footnotetext{
${ }^{12}$ Since, I can always rescale $\mathrm{g}(\mathrm{A})$, this normalization does not entail loss of generality.
} 
code is) and the tax code uses the comparative statics of A with respect to $t$ and B.

(12) $\partial \mathrm{A} / \partial \mathrm{t}=-\mathrm{f}^{\prime \prime}(1)^{2} /\left(\mathrm{g}^{\prime \prime}(\mathrm{A})\left(\mathrm{tf} \mathrm{f}^{\prime \prime}(1)-\mathrm{B}(1+\mathrm{t})\right)^{2}\right)>0$, and

(13) $\partial \mathrm{A} / \partial \mathrm{B}=\mathrm{f}^{\prime \prime}(1)(1+\mathrm{t})^{2} /\left(\mathrm{g}^{\prime \prime}(\mathrm{A})\left(\mathrm{tf} \mathrm{f}^{\prime \prime}(1)-\mathrm{B}(1+\mathrm{t})\right)^{2}\right)>0$.

Using these equations, the voters must decide on the optimal tax rate for lump sum taxes and for property taxes. Since land density always equals one and population always equals one, there are in fact no distortions coming from taxation (the model was particularly rigged to create this simplifying result). The only goal of tax policy is to maximize government incentives while minimizing the revenues paid to government (since taxes do no good in this model). While it is fairly easy to solve out the complete tax policy problem, more intuition is gained by asking whether are not a revenue neutral switch from property taxes to lump sum taxes raises or decreases the amenity levels. For a tax policy change to be revenue neutral, it must be that:

(14) $d[t P+B]=0$ or $P d t+t d P+d B=0$.

Since $\mathrm{L}$ will not change with $\mathrm{t}$ (as the voters know that each locality will be affected identically by any change in tax regime), differentiating (3) with respect to $t$ yields:

(15) $d P(1+t)+P d t=0$.

Substituting (15) into (14) gives:

(14') $\mathrm{dB}=-\mathrm{Pdt} /(1+\mathrm{t})$.

or the increase in the lump sum tax is exactly offset by the decrease in the property tax rate times the price of property. To see if this change increases the amount of amenities it must be that:

(16) $\mathrm{dB}(\partial \mathrm{A} / \partial \mathrm{B})+\mathrm{dt}(\partial \mathrm{A} / \partial \mathrm{t})>0$, or $\mathrm{dB}[(\partial \mathrm{A} / \partial \mathrm{B})-(\partial \mathrm{A} / \partial \mathrm{t})((1+\mathrm{t}) / \mathrm{P})]>0$ 
Substituting (12), (13), (14'), dB>0, and the definition of the elasticity of demand for housing into (16), that inequality becomes:

(16') $\varepsilon_{\mathbb{D}}>1$

Thus, a revenue neutral switch to lump sum taxation generates an increase in total amenity levels if the elasticity of demand for housing is greater than 1. This inequality is the basic intuition of the model. When housing demand is inelastic increases in local amenity levels show up as increases in property values: therefore the incentive effects of local property taxation on local governments are strong. When housing demand is highly elastic, then increases in local amenity levels when inspire in-migration and good amenity provision will reflect itself in larger populations. In that case, tying revenues to the total population of the community through lump sum taxes makes more sense.

In fact, traditional estimates of the price elasticity of housing suggest that this elasticity either close to or less than one. Muth (1968) argues that the own price elasticity of housing is approximately unity. In her classic study, Reid (1962) argues for a less elastic estimate of .75. Other estimates show considerable variation in the elasticity of demand for housing across cities.

The model is certainly not general, but many features could be broadened without losing the basic results. Dropping the functional form assumption on utility is fairly irrelevant, except that allowing non-separability creates intense notational complexity. Allowing more heterogeneity across areas would not matter. The critical assumption is that governments are revenue maximizers and that the tax rates are fixed simultaneously on all districts. ${ }^{13}$ The assumption on revenue maximization is justified extensively in Niskanen (1979) and Brennan and Buchanan (1977).

One of the pervasive questions of property taxes is why these taxes are so much more common on the local level than they are at the national level?

\footnotetext{
${ }^{13}$ When maximum tax rate are fixed by each local community taking the tax rates of the other communities as given, the algebra gets more complicated since the locality cannot assume that changes in the tax rate will leave the population of that locality unchanged. The intuition, however, cannot change.
} 
This model presents an simple explanation. Property values do not reflect amenities on a nationwide level nearly as clearly as they do on the local level, because the migration costs between countries are so much higher than the migration costs between jurisdictions. Imagine for example a large increase in the amenity levels in all $Q$ of the jurisdictions in the above model. This increase would not lead to any increase in property values, which are basically fixed at $f^{\prime}(1) /(1+t)$ at the national level. Of course, lump-sum taxes don't provide strong incentives on national governments either when migration is impossible.

\section{Model 2: Local Property Taxes and Time Horizons}

This model extends the previous model to two periods. Again, the basic situation is the same. Consumers make locational decisions taking government actions as given. Governments make amenity choice decisions take tax rates, consumer reaction functions and other governmental choices as given. Tax rates are again on property and lump sum. However, now there are two periods. Agents freely choose to move in each period and the agents can move costlessly.

In this model, amenities are created the period before they are utilized. Examples of such amenities include everything from investing in school buildings to stricter regulation on polluters. In the first period, amenity levels are arbitrarily set to zero. ${ }^{14}$ In the second period amenity levels are equal to the amenity investment made by the government in the first period. The amenity level in the first period is chosen to maximize net discounted revenues of the government, and there is some probability that the government will be voted out of office at the end of the first period, $\delta(A)$. This probability can be a function of the amenity investment provided as well.

This model must start with the land market. The price of land in the second period again will be determined by how much agents want to live in that area during that period. The price of land in the first period reflects the value of

${ }^{14}$ Allowing amenity provision for both periods would complicate the results but not change the basic intuition. 
the use of the land in the first period plus the expected discounted price of the property in the second period. I will a new quantity, property rent, $R$, which the value of the property in the first period:

(17) $R_{1}=P_{1}-P_{2} /(1+r)$,

or the implicit rent in period is equal to the price of housing in period one minus the discounted price of the housing in period two ( $\mathrm{r}$ is the interest rate).

Agents' decisions have no temporal features. Migration is costless in each period, so in each period, equation (4), the indifference equation, must hold. Now the basic consumer relations from the first section remain in the second period (with $\mathrm{P}_{2}$ replacing $\mathrm{P}$ ):

(18) $I-B-P_{2}(1+t) L+f(L)+g(A)=$ Reservation Utility,

and they remain in the first period (with $R_{1}$ replacing $P$ ):

(19) $I-B-R_{1}(1+t) L+f(L)+g(0)=$ Reservation Utility.

The rent in the first period does not change with the amenity level because agents living in the locality in the first period derive no utility from amenities investment in that period. However, the property value in the second period goes up with the amenity investment, or:

(20a) $P_{2}^{\prime}(A)=g^{\prime}(A) /(1+t)$, which tells us that:

(20b) $P_{1}^{\prime}(A)=g^{\prime}(A) /(1+r)(1+t) \cdot{ }^{15}$

Likewise the total population in the first period is unaffected by the amenities provided in the first period, but the population in the second period is driven by the amenities provided in the first period, or:

${ }^{15}$ I have used the fact that $\mathrm{N}=\mathrm{L}=1$ here as I will throughout the rest of the paper. 
(20c) $\mathrm{N}_{2}^{\prime}(\mathrm{A})=-\mathrm{g}^{\prime}(\mathrm{A}) / \mathrm{f}^{\prime \prime}(1)$.

The government will then set local amenity levels to maximize the discounted value of expected revenues minus outlays on the first period amenity, or:

(21) $t \mathrm{P}_{1}(\mathrm{~A})+\delta(\mathrm{A})\left[\mathrm{tP}_{2}(\mathrm{~A})+\mathrm{BN}_{2}(\mathrm{~A})\right] /(1+\mathrm{r})-\mathrm{A}$.

The first order conditions for this problem are:

$$
\begin{gathered}
1=\operatorname{tg}^{\prime}(\mathrm{A}) /(1+r)(1+\mathrm{t})+\delta(\mathrm{A})\left[\operatorname{tg}^{\prime}(\mathrm{A}) /(1+\mathrm{t})-\mathrm{Bg}^{\prime}(\mathrm{A}) / \mathrm{f}^{\prime \prime}(1)\right] /(1+\mathrm{r})+ \\
\delta^{\prime}(\mathrm{A})\left[\mathrm{tP}_{2}(\mathrm{~A})+\mathrm{BN}_{2}(\mathrm{~A})\right] /(1+\mathrm{r})
\end{gathered}
$$

The incentives for government investment in this case come from three sources (1) increased revenues from current property values, (2) increases revenues from future property and lump-sum taxes and (3) electoral incentives. As we can see straightforwardly, the initial property taxes are the only incentives which bind as the electoral effects or as electoral stability disappears. So immediately it is obvious that in extremely unstable electoral systems, property taxes insure greater incentives than lump-sum taxes (or any taxes based on a current flow rather than an expected future flow).

Including incentive effects of elections is not meant to add seriously to the literature on these effects (begun by Downs (1957)). Instead, I meant merely to show that the basic results would be unchanged in I include other incentives beyond taxes. In the case where $\delta(A)=\delta$, I can ask simply the same question as I asked in the previous section: when does a revenue neutral shift towards lump sum taxes increase the incentives for amenity levels. In this case, the solution for A becomes:

(23) $A=g^{\prime}-1\left[\left(f^{\prime \prime}(1)(1+t)(1+r) /\left(t(1+\delta) f^{\prime \prime}(1)-\delta B(1+t)\right)\right]\right.$,

and the comparative statics are:

(24) $\partial \mathrm{A} / \partial \mathrm{t}=-(1+\delta)(1+\mathrm{r}) \mathrm{f}^{\prime \prime}(1)^{2} /\left(\mathrm{g}^{\prime \prime}(\mathrm{A})\left(\mathrm{t}(1+\delta) \mathrm{f}^{\prime \prime}(1)-\delta \mathrm{B}(1+\mathrm{t})\right)^{2}\right)$, and 
(25) $\partial \mathrm{A} / \partial \mathrm{B}=\mathrm{f}^{\prime \prime}(1) \delta(1+\mathrm{t})^{2} /\left(\mathrm{g} "(\mathrm{~A})\left(\mathrm{t}(1+\delta) \mathrm{f}^{\prime \prime}(1)-\delta \mathrm{B}(1+\mathrm{t})\right)^{2}\right)$.

Now when I perform the same experiment, looking to seem if the amenity levels rise with a switch to lump sum taxes I see that the requirement is:

(26) $\left(\varepsilon_{\mathrm{D}}{ }^{1}+2 \varepsilon_{\mathrm{D}}{ }^{2} /(1+\mathrm{r})\right)>(2+\mathrm{r})(1+\delta) / \delta$,

where:

(27a) $\varepsilon_{D}^{1}=-f^{\prime \prime}(1) /(1+t) R_{1}$, and

(27b) $\varepsilon_{D}^{2}=-f^{\prime \prime}(1)(1+r) /(1+t) P_{2}$.

(26) generally represents a more stringent condition than (16') -- property taxes always provide relatively better incentives for investment decisions than they do for one-period amenity provisions. Furthermore, the durability of the government plays a crucial role in determining the value of the property taxes. The lesser the likelihood that the government will remain in power, the more valuable property taxes become relative to lump-sum (or other flow based taxes) in providing incentives for taking long-term actions. In the case of extreme myopia $(\delta=0)$, lump-sum taxes (or any tax based on current conditions) will create no incentives whatsoever. This point is very similar to the idea that CEOs are given good incentives for long range planning when their compensation is based on the stock price, which should reflect expectations about the companies future profits.

\section{IV: Model 3: Local Property Taxes and Endogenous Tax Rates}

The preceding sections have taken local tax rates as given and asked how these tax rates affect amenity provision. Of course, in reality tax rates are frequently flexible. Local governments can, subject to voter control, set the tax rates that they themselves face. One of the primary advantages of local property taxes is that local property values fall as any other local tax rises, so the existence of local property taxes serves to check all of the other tax rates. 
This model explores the a situation :vhere local taxes are determined endogenous. Here I assume that amenity levels are fixed at zero, so I can ignore amenities. The representative agent's utility function becomes:

(28) $U(X, L)=I-B-P(1+t) L+f(L)$.

The first order condition on land and the indifference condition both still apply:

(29) $P(1+t)=f^{\prime}(L)$, and

(30) $I-B-P(1+t) L+f(L)=$ Reservation Utility.

Differentiating (29) and (30) and using $L=1$ in equilibrium tells us that:

(31) $\partial \mathrm{P} / \partial \mathrm{B}=-1 /(1+\mathrm{t})$,

(32) $\partial \mathrm{P} / \partial \mathrm{t}=-\mathrm{P} /(1+\mathrm{t})$,

(33) $\partial \mathrm{N} / \partial \mathrm{B}=1 / \mathrm{f}^{\prime \prime}(1)$, and

(34) $\partial \mathrm{N} / \partial \mathrm{t}=0$.

The reason why population reacts to changes in the lump-sum tax rate, but not to changes in the property tax rate, is that population only changes when $P(1+t)$ changes. As the property tax rate rises, the property price falls perfectly to adjust for it, so the overall change in $P(1+t)$ is zero. However, in the case of lump-sum taxes, the price of property falls as the price of property rises so that consumers are indifferent between this community and all the others. So $P$ has fallen and $1+t$ is unchanged, which means that the price per unit of land has gone down and the land density will go down as well as consumers purchase more land. ${ }^{16}$

\footnotetext{
${ }^{16}$ These results hinge critically on the separability of land and amenities.
} 
The government chooses its own tax rates knowing these reaction functions. I assume that there is some arbitrary cost of taxation $C(t, B)$ that effectively will limit taxation but that otherwise the government just maximizes revenues. The $C(t, B)$ function may come from popular unrest or electoral problems or actual financial compensation of the officials. ${ }^{17}$ This function may itself be chosen by the voters. The government's maximization problem becomes:

(32) $t P(t, B)+B N(B)-C(t, B)$,

which has first order conditions:

(33) $P /(1+t)=\partial C / \partial t$ and

(34) $1 /(1+t)+B / f^{\prime \prime}(1)=\partial C / \partial B$.

From these equations, it is immediately obvious that without the somewhat ad hoc cost function, the revenue maximizing property tax rate is undefined. However, it is also obvious that the higher the property tax rate, the lower the marginal return to lump sum taxes. In the extreme case where the government received all the revenues from property, there would be no lump-sum taxes whatsoever. This role of property taxes would be particularly valuable if other forms of taxation are highly distortionary (which they are not here). In that distortionary case, the presence of a property tax may help to limit the amount of negative taxation that occurs. One way to view equation (34) is that property taxes are strong substitutes for taxes on other goods.

In the case above I can ask the simple question, does an increase in the property tax rate ever lower the total tax burden on consumers. Here, I imagine that the government is choosing lump-sum taxes and the citizens are deciding whether to lower $\partial \mathrm{C} / \partial \mathrm{t}$ to have the government raise the property taxes. A rise in the property taxes will lower the total tax burden if:

${ }^{17}$ Technically, this function is necessary to reach an interior solution for taxes on property and to provide comparative statics for constitutional reform. 
(34) $\partial[\mathrm{tP}(\mathrm{t}, \mathrm{B}(\mathrm{t}))+\mathrm{B}(\mathrm{t})] / \partial \mathrm{t}<0$, or $\mathrm{P}+\mathrm{t} \partial \mathrm{P} / \partial \mathrm{t}+\partial \mathrm{B} / \partial \mathrm{t}(\mathrm{t} \partial \mathrm{P} / \partial \mathrm{B}+1)<0$.

Substituting in, when $\partial^{2} \mathrm{C} / \partial \mathrm{B} \partial \mathrm{t}$ equals zero:

(34) $1 /(1+t)>\varepsilon_{D}$,

or the elasticity of demand for housing is larger than the one divided by one plus the tax rate on housing. So again, when the demand for housing is sufficiently inelastic a rise in the property tax rate (or more precisely a decrease in the cost of taxing property) will overall improve voter welfare and, in this case, lower overall revenues.

\section{Extensions}

This section gives some quick extensions to the above models.

\section{Property Assessment}

One peculiar feature of property taxes is that frequently local governments do not assess property values at current market rates. Property values are often assessed irregularly or only at the time of sale. Occasionally legal barriers restrict governments abilities to assess current market values. The Statistical Abstract of the U.S. shows that the range of assessed values to true market values across U.S. cities ranges from under $10 \%$ (in the case of New York city) to almost $100 \%$. Of course, in the above model the degree of assessment is easy to include in the model. The tax rate in the first model $t$, can be replaced with:

(35) $t=t_{N}\left((1-\sigma) P_{0}+\sigma P\right) / P$,

where $P_{0}$ is the old value of the land, $t_{N}$ is the official tax rate, and $\sigma$ represents the percent of the building stock that is regularly assessed. The consumers conditions are essentially unchanged by this substitution: Making this substitution into the government's first order conditions tells us that the government's first order conditions become: 
(3ó) $P^{\prime}(A) \sigma t_{N}+N^{\prime}(A) B-1=0$.

From (36), it is immediately obvious that the degree to which land is regularly assessed strongly determines the amount of incentives facing local governments through property values. When assessment rates are rare and irregular, the incentive effects of property taxation disappear.

From this point it is immediately obvious that a natural test of the theory lies with assessment frequencies (holding tax revenues constant) not with effective tax rates (i.e. nominal tax rates times assessment rates) themselves (which I cannot vary without varying tax revenues). A rise in assessment rates, holding effective tax rates constant, increases the level of incentives without increasing the revenues available to local governments. Looking across local government assessment rates provides a test of the theory if there also exists a measure of amenity provision.

Furthermore, this model suggests that increasing assessment accuracy (while lowering the overall tax rates) provides us with a revenue-neutral means of increasing incentives for local governments. Conversely, it seems clear that when I observe a decrease in assessment rates (as I did in Proposition 13), this decrease suggests that voters no longer thought that property taxes provided any useful incentives. If voters, because property values have begun to reflect too many things beyond amenity provision, turn against the incentive role of property taxes than lowering assessment rates is the easiest way to limit these incentives.

\section{Shocks to Property Values}

The last point, about property values reflecting shocks other than amenity values, is the subject of this section. In this situation consider a world in which property values are equal to $\mathrm{P}(v \mathrm{~A}+(1-v) \xi)$, where $v$ represent the importance of random shocks to housing prices and $\xi$ represents those random shocks. In this case, the governments maximization condition becomes:

(37) $P^{\prime}(v A+(1-v) \xi) v t+N^{\prime}(A) B-1=0$. 
Again, as the importance of amenities to property values falls (as $v$ falls) the overall level of incentives also falls. So, if there are substantial shocks to a housing market created by external forces (demand for California sunshine or other amenities not determined by the government), then the incentive value of property taxes declined. As I will argue later, one interpretation of Proposition 13, is that property value changes in the 1970s in California were so unconnected with local amenity levels that they eliminated the incentive value of property taxes.

\section{Perverse Incentives}

A final point about the value of property taxes is that property values are often the closest thing to the utility function of a locality. When agents are mobile, it makes little sense for a locality to maximize the welfare of a particular set of agents. In general, the locality wants to maximize the social surplus possessed by its agents and when property owners can sell the right to live in the locality, property values exactly reflect this social surplus. Since property values closely reflect the actual desired maximand of the local governments, basing revenues on property values matches most closely the government's incentives with the things that they should be maximizing.

In theory, of course, there is no reason why contracts for agents can't be written on anything that reflects the desired output of the agents. In a world, however, agents can always try to act directly on the object in the contract rather than on the desired output. For example, if what is desired from a baseball player is overall quality playing, but the contract for the player pays out only with regard to batting average, then the player may boost his batting average at the expense of his hitting for power or fielding.

In the context of local governments, this point means that when taxes are on something other than property values (but that may be related occasionally to property values) local governments may boost the object being taxed at the expense of property values and social welfare. In the case of lump-sum taxes, it is possible that the government may act to attract a particular group of people who own less land per capita (perhaps poorer citizens) just to 
maximize the government's total head ccunt. In the case of taxes on a particular commodity, the government may make a variety of decisions hurting property values to maximize the sales of that commodity. Only be focusing taxes only on property values (the actual social welfare aim) can the constitution ensure that the government maximizes what it should and avoids any perverse incentives.

\section{Tax Reform in the 1970s: Proposition 13}

Many of the events of property tax reform are compatible with the previous models. ${ }^{18}$ While the majority interpretation of Proposition 13 is that this proposition represents an attack on governmental leviathan (Brennan and Buchanan (1980), Fischel (1989) has argued an alternative interpretation: Proposition 13 was a direct result of Priest $v$. Serrano (hereafter Serrano). In Serrano (and two subsequent Serrano rulings, the California Supreme Court required homogeneity in local expenditures on schooling across districts. This homogeneity (essentially that school districts spend within $\$ 100$ per pupil of one another) in theory limits any ability of the government to allocate funds towards school improvements.

Fischel (1989) takes a Tiebout (1956) view of the world and argues that the primary function of having localized (rather than state or federal) control of a service is to enable different people to consume different quantities of the service by living in different localities. When Serrano eliminated the possibilities of differing service levels across locations, the whole function of local property taxes was eliminated and the state optimally chose to move to a statewide tax system. Fischel presents a series of evidence supporting his view over the more traditional leviathan view. While, I certainly agree with Fischel's logic, I also believe that the incentive view of property taxation can also explain a connection between proposition 13 and Serrano. As Serrano eliminated many of the functions of local government incentives, it eliminated the need for higher property taxes.

\footnotetext{
${ }^{18}$ Rabushka and Ryan (1982) provide a detailed discussion of the California tax reform movement.
} 
Furthermore, Proposition 13 had particular features which suggest yet another explanation of why it was so successful. The efficiency of property taxes as incentive devices depends on the degree to which local government actions determine property values. As property values rose in the late $1970 \mathrm{~s}$ (Proposition 13 was preceded by the extraordinary boom in the California real estate market), the share of the government's contribution to property value changes to the share of all the other forces changing property values seems to have fallen. Certainly the rhetoric of the advocates of Proposition 13 showed no evidence of suggesting that the state contributed to property value increases.

Because property values in the late 1970 s were being changed more by a general demand for California land than by government actions, property taxes had become an increasing expensive and inaccurate way to achieve government incentives. The voters may have reacted to these shocks to property values by turning away from property taxes. The voters actions: lowering property tax values, and even more importantly, forcing assessed values to be tied to their 1975 levels basically undermined the role of property taxes as incentives, which may have been optimal if property taxes no longer provided efficent incentives.

One set of results from the analysis of the tax reforms of the late 1970s are those of Preston and Ichniowski (1991) who show that despite a very strong connection between states with local tax reform and states with declining local tax revenues, the connection between local tax reform and overall tax revenue declines is small. The third model provides a justification for the high degree of substitution between property taxes and other taxes. As local governments became less dependent on local property tax revenues, these governments also acquired fewer incentives to keep alternative taxes low. Presumably these governments also acquired a greater need for other taxes.

A second result of tax reform (which made by Fischel) is that overall service (and particularly schooling) qualities declined in California after Proposition 
13.19 However, the results of Downes (1992) do not suggest that the declines in schooling quality were very connected to declines in schooling expenditures. Downes (1992) shows that the districts where tax reforms lowered revenues did not significantly fall in their educational quality and the districts where Serrano and tax reform raised expenditures did not rise in educational quality. This work suggests that a simple view where reduced earnings created worse services does not seem to be born out in the data. An alternative view of the general quality decline is that it came as a result of weaker incentives for local governments. These weaker incentives came because local governments were less tied to revenues from local property values and more tied to intergovernmental transfers.

\section{Conclusion}

This essay has argued that property taxes serve as incentive devices on local governments. These property taxes act to make the government a part owner of local real estate. Like any other owner, the government thus acquires an incentive to provide amenities and take actions that raise property values. This incentive supports amenity provision generally, but in particular it provides strong intertemporal incentives which may be important if governments are unstable and therefore myopic. Furthermore, the property tax serves to limit the taxation of other commodities since higher taxes on other commodities will lower property values and property tax revenues.

${ }^{19}$ I will not argue the accuracy of this claim. Many aggregate measures show schooling declines; some aggregate measures do not show such a decline. Fischel (1989) provides strong support for this claim. 


\section{References}

Atkinson, A. and J. Stiglitz, (1980) Lectures on Public Economics. New York: Mc Graw Hill.

Brennan, G. and J. Buchanan (1980) The Power to Tax. Cambridge: Cambridge University Press.

Brennan, G. and J. Buchanan (1978) "Tax instruments as constraints on the disposition of tax revenues," Journal of Public Economics 9: 301-318.

Brennan, G. and J. Buchanan (1977) "Towards a tax Constitution for Leviathan," Journal of Public Economics 8: 255-274.

Downes, T. A. (1992) "Evaluating the impact of school finance reform on the provision of public education: the California case." National Tax Journal $X L V:$ 405-420.

Downs, A. (1957) An Economic Theory of Democracy. New York: Harper and Row.

Fischel, W. (1989) "Did Serrano cause Proposition 13?" National Tax Journal XLII: 465-474.

George, H. (1935) Progress and Poverty. Robert Schalkenbach Foundation: New York.

Maxwell, J. (1965) Financing State and Local Government. The Brooking Institution: Washington.

Muth, R. (1968) "Urban Residential Land and Housing Markets," in Perloff and Wingo Eds. Issues in Urban Economics. Johns Hopkins Press: Baltimore.

Niskanan, W. A. (1971) Bureaucracy and Representative Government. Chicago, Aldine.

Preston, A. and C. Ichniowski, (1991) "A National Perspective on the Nature and Effects of the Local Property Tax Revolt: 1976-1986," National Tax Journal XLIV: 123-146.

Rabushka, A. and P. Ryan (1982) The Tax Revolt. Hoover Institution Press: Stanford.

Ramsey, F. (1927) "A Contribution to the Theory of Taxation," Economic Journal 37: 47-61.

Reid, M. (1962) Housing and Income. University of Chicago Press: Chicago.

Rosen, H. (1985) Public Finance, Homewood, IL: Richard D. Irwin, Co.

Tiebout, C. (1956) "A Pure Theory of Local Expenditure," Journal of Political Economy 64. 